\title{
Hukum Islam dan Politik Hukumnya dalam Hukum Nasional
}

\author{
Syaifullahil Maslul ${ }^{1}$ Achmad Arif $^{2}$ \\ ${ }^{1 \& 2}$ Universitas Darussalam Gontor, Jl. Raya Siman Kab. Ponorogo \\ Email: ${ }^{1}$ maslulsyaif@gmail.com dan ${ }^{2}$ achmadarif@unida.gontor.ac.id
}

\begin{abstract}
Development of National law must pay attention to many aspects, one of which is Islamic law. Islamic law itself has become part of three main sources of law that build national law, namely Islamic law, customary law and western law. Thus, it is important to understand how the legal basis and politics of Islamic law is in the development of national law in the future. This study was conducted in a normative and sociological approach, that Islamic law is guided and preserved by Muslim communities. The results of this study showed; first, the Islamic legal basis in National law is the first principle of the Pancasila and Article $28 \mathrm{E}$ paragraph (1), (2) and Article 29 of the constitution. Pancasila and a quo Articles are not only guarantee the implementation of ubudiyah, but also which are divided into muamalat, munakahat, and jinayat. Various rules have been issued in these fields. Second, the politics of Islamic law in the future must build maintain the Islamic law and renewal (tajdid) of Islamic law in Indonesian context.
\end{abstract}

Keywords: Political Law of National Laws

\begin{abstract}
Abstrak:
Pembangunan hukum Nasional harus memperhatikan banyak aspek, salah satunya hukum Islam. Hukum Islam sendiri telah menjadi bagian dari tiga sumber hukum mainstream yang membangun hukum Nasional, yaitu hukum Islam, hukum adat dan hukum barat. Maka, bagaimana dasar hukum dan politik hukum Islam dalam pembangunan hukum Nasional di masa mendatang. Kajian ini menggunakan pendekatan normatif atau statute approach dan pendekatan sosiologis, bahwa hukum Islam dipedomani dan dilestarikan oleh masyarakat muslim. Hasil dari kajian ini menunjukkan; pertama, dasar hukum Islam dalam hukum Nasional adalah sila pertama pancasila dan Pasal 28 E ayat (1), (2) dan Pasal 29. Pancasila dan Pasal-pasal a quo, tidak hanya menjamin pelaksanaan ubudiyah, namun juga yang bersifat muamalat yang terbagi dalam muamalat, munakahat, dan jinayat. Berbagai aturan telah dikeluarkan dalam bidang-bidang tersebut. Kedua, politik hukum Islam di masa mendatang harus membangun dan memperjuangkan hukum Islam dan pembaharuan (tajdid) dalam hukum Islam dalam konteks Indonesia.
\end{abstract}

Kata Kunci: Hukum Islam-Politik Hukum-Hukum Nasional. 


\section{Pendahuluan}

Pembentukan hukum memiliki kekhasannya sendiri. Oleh karena hukum tidak dibentuk di ruang hampa sehingga terhindar dari aspek-aspek lain di luar hukum. Hukum tidak bisa menghindar dari berbagai aspek yang timbul di zaman ini. Pengaruh tersebut menimbulkan dinamika dalam pembentukan hukum. Setidaknya, hukum dalam pembentukanya dipengaruhi oleh lima aspek di antaranya; sumber hukum, filsafat hukum, tujuan hukum, legislasi hukum dan fakta-fakta sosial. ${ }^{1}$

Indonesia adalah Negara dengan mayoritas penduduknya penganut agama Islam. Populasi ini adalah populasi besar yang pada setiap dinamikanya memerlukan perhatian. Salah satu bentuk perhatiannya adalah dengan memberikan keleluasaan dalam beribadah. Jaminan beribadah diberikan landasannya dalam sila Pertama Pancasila "Ketuhanan Yang Maha Esa". Turunan daripada sila pertama ini secara eksplisit diatur dalam UUD 1945.

Pengaturan jaminan beribadah dituangkan dalam Pasal 28E ayat (1) dan (2) serta Pasal 29. Jaminan ini tidak bersifat parsial, namun secara komprehensif diterapkan bagi seluruh rakyat Indonesia. Meskipun begitu, populasi yang besar serta tuntutan pelaksanaan beragama Islam yang besar, haruslah mendapatkan perhatian yang besar pula.

Negara dalam kapasistasnya sebagai pengambil kebijakan secara adil dalam membentuk hukum dengan berorientasi pada keadilan. Hukum idealnya dibentuk dengan mempertimbangkan terwujudnya suatu nilai-nilai keadilan. ${ }^{2} \mathrm{Hal}$ itu senada dengan tujuan hukum yang disebutkan oleh Gustav Radbruch yang menyebutkan bahwa tujuan hukum ada tiga yakni untuk menwujudkan keadilan, kemanfaatan dan kepastian hukum. ${ }^{3}$

Salah satu jaminan yang harus diberikan oleh Negara bagi pemeluk agama Islam adalah jaminan beribadah yang dituangkan dalam peraturan perundang-

${ }^{1}$ Pada poin keempat, maksud dari legislasi hukum adalah proses hukum. Di dalam proses legislasi tidak bisa dipungkiri akan terjadi kontak kepentingan dan tukar pikiran dari para pembentuk dan ahli hukum. Proses ini terkadang justru menjadi penentu akhir dari hukum.

${ }^{2}$ Abus Salam, Pengaruh Politik Dalam Pembentukan Hukum di Indonesia (Mazahib: Jurnal Pemikiran Hukum Islam, Vol. XIV, No. 2 (Desember 2015)), h. 119.

${ }^{3}$ Ahmad Ali, Menguak Tabir Hukum (Bogor: Ghalia Indonesia, 2011), h. 67. 
undangan di Indonesia. Hal ini adalah tujuan daripada hukum, yaitu untuk menwujudkan keadilan. Keadilan tidak selalu berbicara persamaan, namun juga berbicara soal kebutuhan dan kepentingan selama tidak merugikan pihak lainnya.

Selain daripada itu, Indonesia adalah Negara dengan kemajemukan hukum. Hal ini dapat dirunut dari kemajemukan pemberlakuan hukum di Indonesia, dari hukum Islam, hukum Adat dan hukum Barat. ${ }^{4}$ Sehingga pemberlakuan hukum Islam, nyata-nyata memiliki tempat di dalam hukum Nasional di Indonesia. Hukum Islam bersama dengan sistem hukum lainnya secara bersamaan telah mengisi hukum Nasional sesuai dengan porsi dan kebutuhannya.

Kajian ini akan membedah secara mendalam soal dasar hukum pembentukannya dalam legislasi di Indonesia dan arah politik hukum Islam di masa mendatang di Indonesia. Kajian ini dimaksudkan memberikan pengetahuan dasar hukum legislasi hukum Islam dan menyoal hukum Islam di masa mendatang.

\section{Metodologi}

Penulisan hukum ini menggunakan pendekatan hukum normatif (statute approach) dengan memperhatikan berbagai peraturan perundang-undangan. Peraturan perundang-undangan yang dimaksud adalah yang berkaitan dengan pembentukan hukum Nasional di Indonesia. Selain itu, pendekatan lainnya adalah pendekatan sosial. Hal ini merujuk pada fakta-fakta bahwa hukum Islam dipedomani oleh mayoritas penduduk indonesia.

\section{Pembahasan}

\section{Dasar Hukum Positivisasi Hukum Islam}

Sumber hukum secara sederhana dimaknai sebagai tempat diperoleh hukum. Sumber hukum dapat dilakukan dua hal, yakni: (1) membawa kepada

${ }^{4}$ Mardani, Kedudukan Hukum Islam dalam Sistem Hukum Nasional (Jurnal Hukum No. 2 Vol. 16 April 2009), h. 267. 
suatu penyelidikan tentang wewenang dan; (2) hal-hal yang dapat atau seyogyanya mempengaruhi kepada pengusa di dalam menentukan hukum. ${ }^{5}$

Sumber hukum memberikan jalan penyelidikan dan perunutan terhadap pembentukan hukum. Dimungkinkan pemahaman yang utuh terhadap hukum yang diterapkan. Hal ini karena corak yang dibawa oleh sumber hukum. Selain itu, sumber hukum sebagaimana poin kedua di atas, memberikan asupan materi yang cukup yang memiliki pengaruh signifikan bagi penguasa atau pembentuk hukum.

Sumber hukum dibagi kedalam sumber hukum formil dan sumber hukum materil. ${ }^{6}$ Sumber hukum formil adalah sumber pengambilan hukum berdasarkan cara terjadinya atau pembentukannya seperti, peraturan perundang-undangan, perjanjian antar negara, yurisprudensi dan kebiasaan. Sedangkan sumber hukum materil adalah sumber hukum dilihat dari materi atau muatan hukum itu berasal, seperti hubungan sosial, hubungan kekuatan politik, situasi sosial ekonomis, tradisi (pandangan keagamaan, kesusilaan), perkembangan internasional, dan keadaan geografis.

Di Indonesia, Pancasila adalah sumber dari segala sumber hukum. Pemahaman pancasila sebagai sumber dari segala sumber hokum adalah: (1) ideologi hukum Indonesia; (2) kumpulan nilai-nilai yang harus berada di belakang keseluruhan hukum Indonesia; (3) asas-asas yang harus diikuti sebagai petunjuk dalam mengadakan pilihan hukum di Indonesia dan; (4) sebagai suatu pernyataan dari nilai kejiwaan dan keinginan bangsa Indonesia, juga dalam hukumnya. $^{7}$

${ }^{5}$ Theresia Ngutra, Hukum dan Sumber-Sumber Hukum (Jurnal Supremasi: Volume XI Nomor 2, Oktober 2016), h. 194.

${ }^{6}$ Sudikno Mertokusumo, Mengenal Hukum, Edisi Revisi (Yogyakarta: Cahaya Atma Pustaka, 2010), h. 107.

${ }^{7}$ Roeslan Saleh, Penjabaran Pancasila dan UUD 1945 (Jakarta: Aksara Baru, 1979), h. 49. 
Syaifullahil Maslul:

Pengaturan pancasila sebagai sumber dari sumber hukum tertuang dalam Pasal 2 Undang-Undang Nomor 10 tahun 2004 jo. Undang-Undang Nomor 12 Tahun 2011 tentang Pembentukan Peraturan Perundang-undangan. ${ }^{8}$

Pada tataran ini, Pancasila tidak saja sebagai sumber dari segala sumber. Namun juga menjadi muara dari pergumulan pluralitas sumber hukum yang ada di Indonesia. Persoalan ini tidak terlepas dari pembangunan sistem hukum Nasional Indonesia yang didasarkan tiga sistem hukum mainstream yaitu hukum adat, hukum barat dan hukum Islam. ${ }^{9}$ Pluralitas ini dipicu oleh: pertama, hukum adat/ kebiasaan yang dianut oleh masyarakat hukum adat yang kemudian secara turun temurun dan terus menerus dilestarikan oleh masyarakat hukum adat. Hukum ini kemudian terlembagakan dan mendapat tempat dalam sistem hukum Nasional dengan diberlakukannya Pasal 18B UUD 1945.

Kedua, pemberlakukan sistem hukum kolonial yang sampai saat ini belum bisa digantikan. Pada saat itu, penjajah secara paksa menerapkan sistem konkordansi, bahwa hukum yang berlaku adalah hukum kolonial. Hal ini memicu dikemudian hari, hukum-hukum yang belum ada saat awal kemerdekaan diisi oleh sistem hukum kolonial atau barat. Ketiga, hukum-hukum agama atau hukum Islam yang diyakini sebagai pedoman berkehidupan. Ketiga faktor ini yang yang kemudian dijembatangi dan diberikan ruang oleh Pancasila. Meskipun begitu, Daniel S. Lev yang menyatakan bahwa sistem hukum Indonesia merupakan satu dari sekian banyak sistem hukum yang lebih rumit di dunia. ${ }^{10}$

Hukum Islam secara materil telah memiliki tempat sebagai sumber hukum dalam sistem hukum Nasional. Pemaparan di atas dalam fakta sosiologis yang berkembang di dalam masyarakat Indonesia. Masyarakat Indonesia yang beragama Islam secara terus menerus menjaga dan melestarikan hukum Islam

${ }^{8}$ Sebelum diundangkannya Undang-Undang Nomor 10 Tahun 2004 dan Undang-Undang Nomor 12 Tahun 2011, Pengaturan Pancasila sebagai sumber dari segala sumber hukum diatur dalam Ketetapan MPR No. XX/MPRS/1966 jo Ketetapan MPR No. V/MPR/1973 jo Ketetapan MPR No. IX/MPR/1978 dan Ketetapan MPR No. III/MPR/2000 tentang Sumber Hukum dan Tata Urutan Peraturan Perundang-Undangan.

${ }^{9}$ Mudzakir, Integrasi Hukum Islam dalam Hukum Nasional: Upaya Restrukturisasi Perundang-undangan Nasional (Jurnal Mazhabuna, No. 2 Tahun II/2003), h. 23.

${ }^{10}$ Daniel S. Lev, Peradilan Agama Islam di Indonesia Suatu Studi Tentang Landasan Politik Lembaga-lembaga Hukum, Alih bahasa oleh Zaini Ahmad Noeh (Jakarta: Intermasa, 1986), h. 24. 
yang ada di Indonesia sekaligus memedomaninya dalam berkehidupan. Hal ini dapat dipersamakan dengan perilaku masyarakat hukum adat yang memedomani dan melestarikan hukum adat.

Dasar hukum yang berikutnya adalah sila pertama pancasila yang berbunyi, "Ketuhanan Yang Maha Esa." Sila pertama memberikan penegasan bahwa salah satu hal yang harus selalu dipedomani bagi masyarakat Indonesia adalah keimanan dan kewajiban berpedoman terhadap agama atau kepercayaan yang dianut, tidak terkecuali agama Islam dan hukum Islam.

Sila pertama dari Pancasila kemudian dipertegas dengan pemberlakuan Pasal 28E ayat (1) dan ayat (2) serta Pasal 29 UUD 1945. Secara tegas dan eksplisit, Pasal-Pasal a quo memberikan jaminan atas pelaksanaan hukum yang berdasarkan agama dan kepercayaan. Jaminan-jaminan ini kemudian dilembagakan dalam sistem hukum Nasional yang sumbernya berasal dari ajaran agama. Artinya, materi muatan yang ada pada peraturan perundang-undangan tersebut bersumber dari ajaran agama termasuk di dalamnya hukum Islam.

Pelembagaan hukum Islam dalam sistem hukum Nasional bukanlah suatu yang baru. Meskipun tidak secara komprehensif dan menyeluruh hukum Islam diterapkan, namun hal ini sudah memberikan penegasan bahwa hukum Islam diakui dalam sistem hukum Nasional.

Dalam hukum Islam, ada dua pembagian: pertama, hukum Islam yang berkaitan dengan ubudiyah atau persolan ibadah yang bersifat vertikal. Hubungan vertikal adalah urusan yang berkaitan hamba dengan Allah swt. Kedua, hukum Islam yang berkaitan dengan muamalat yang terbagi dalam tiga hal yakni: (a) muamalat, yakni berkaitan dengan transaksi antara individu atau biasa disebut dengan ranah privat; (b) munakahat, yakni hukum Islam yang berkaitan dengan perkawinan dan; (c) jinayat yakni hukum Islam berkenaan dengan hukum pidana. Dari sekian pembagian tersebut, hampir semuanya telah diakomodir dalam sistem hukum Nasional.

Persoalan ubudiyah, tegas diberlakukan siapapun mencoba menghalanghalangi seseorang untuk melakukan peribadatan yang dianutnya akan berurusan dengan aparat penegak hukum. Bidang muamalat atau transaski privat telah 
Syaifullahil Maslul:

"Hukum Islam dan Politik Hukumnya dalam Hukum Nasional"

diundangkan Undang-Undang Nomor 7 Tahun 1992 jo. Undang-Undang Nomor 10 Tahun 1998 Tentang Perbankan yang kemudian keluar Undang-Undang Nomor 21 Tahun 2008 tentang Perbankan Syariah. Pemberlakuan UndangUndang a quo memberikan ruang transaksi berdasarkan hukum Islam dan menjamurnya bank-bank syariah.

Dalam munakahat atau perkawinan, sejak tahun 1974 telah diundangkan Undang-Undang Nomor 1 Tahun 1974 tentang perkawinan yang secara materi muatan, mayoritas pengaturan didasarkan pada hukum Islam. Ketiga hal di atas, ubudiyah, muamalat dan munakahat, hukum Islam yang berkaitan dengan jinayat memang belum diterapkan. ${ }^{11}$ Hal ini tidak terlepas masih berlakunya sistem hukum kolonial atau Kitab Undang-Undang Hukum Pidana yang bahkan sampai saat ini belum mendapat kesepakatan untuk dirubah.

\section{Politik Hukum Islam dalam Ius Constituendum}

Sederet bukti sosiologis dan sejarah, hukum Islam sangat erat dengan kehidupan masyarakat Indonesia. Maka tidak bisa dipungkiri banyak ahli yang kemudian menuliskan teori pemberlakukan hukum Islam di indonesia. Teori ini muncul seiring dengan politik hukum yang terjadi. Selain melihat entitas dan originalitas yang ada di masyarkat, teori-teori ini juga menjadi acuan dalam pembentukan hukum Islam menjadi hukum Nasional. Maka, perlu dipaparkan berbagai teori dalam penerapan hukum Islam di Indonesia.

Pertama, teori autoritas hukum. Teori ini menjelaskan penerapan hukum Islam sebagai hal yang harus diterima sebagai konsekuensi beragama Islam. Pemeluk agama Islam harus secara sadar menerima penerapan hukum Islam. Secara sosiologis orang-orang yang sudah beragama Islam menerima autoritas hukum Islam, taat kepada hukum Islam. Tingkatan ketaatan tiap manusia mesti

\footnotetext{
${ }^{11}$ Maksud tidak diberlakukan adalah tidak diberlakukannya secara Nasional. Di Nangroe Aceh Darussalam sendiri, hukum jinayat diberlakukan karena mendapatkan keistimewaan dari negara. Hal ini didasarkan pada Pasal 18B ayat (1): "Negara mengakui dan menghormati satuansatuan pemerintah daerah yang bersifat khusus atau bersifat istimewa yang diatur dalam UndangUndang. Salah satu keistimewaan yang diberlakukan di Aceh adalah penerapan hukum Islam. Hal ini diatur dalam Undang-Undang Nomor 44 Tahun 1999 tentang Penyelenggaraan Keistimewaan Provinsi Daerah Istimewa Aceh.
} 
berbeda-beda, bergantung takwanya kepada Allah. ${ }^{12}$ Penjelasan teori tersebut, dapat dismpulkan pola interaksi seorang muslim dengan hukum Islam, sekaligus penerimaannya terhadap hukum Islam.

Kedua, teori receptie in complexu. Teori ini secara gamblang menjelaskan bahwa hukum yang berlaku bagi para pribumi adalah hukum agamanya. Teori ini diungkapkan oleh Mr. Lodewijk Williem Cristian Van Den Berg. Lodewijk mengusahakan agar hukum kewarisan dan hukum perkawinan Islam dijalankan oleh hakim-hakim Belanda dengan bantuan para penghulu kadi Islam. ${ }^{13}$ Teori ini mungkin berangkat dari penerapan hukum yang parsial di masa kolonial. Pada masa kolonial, berlaku tiga pranata hukum, bagi pribumi, bangsa Eropa dan bangsa Timur Asing. Bagi para Pribumi, berlaku dua hukum, yaitu hukum adat dan hukum agamanya. Dalam teori ini, hukum agama diprioritaskan, karena pribumi telah memeluk agama Islam, maka hukum Islam yang berlaku padanya.

Ketiga, teori receptie. Teori ini mengungkapkan bahwa pada dasarnya bagi para pribumi berlaku hukum adat. Hukum Islam baru berlaku apabila telah diterima hukum adat sebagai hukum. Teori ini menyimpangi teori receptie in complexu. Dasar pemikiran dari teori ini adalah keinginan menjauhkan pribumi yang beragama Islam dari hukum Islam. Mereka yang secara kuat memegang hukum Islam tidak mudah untuk dipengaruhi dengan peradaban barat yang nyatanyata banyak menyimpangi prinsip beragama dalam Islam.

Keempat, teori receptie exit. Teori ini berusaha untuk mengeluarkan teori receptie yang diungkapkan oleh Christian Snouck Hurgronye. Penolakan teori receptie karena selain bertentangan dengan UUD 1945 juga bertentangan dengan Alquran dan hadis. Hazairin mengatakan bahwa theory receptie itu dengan sendirinya sudah dimatikan dengan UUD 1945. Terlebih setelah dikeluarkannya Dekrit Presiden RI tanggal 5 Juli 1959 yang menggambarkan keyakinan Presiden

${ }^{12}$ Kamsi, Politik Hukum Islam Pada Masa Orde Baru, (Jurnal Ishraqi, Vol. 10, No. 1, Juni 2012), h. 3. Lihat juga H.A.R. Gibb, Modern Trends In Islam (Chicago: The University of Chocago, 1972), h. 88.

${ }^{13}$ Ichtiyanto, Pengembangan Teori Berlakunya Hukum Islam di Indonesia," dalam Juhaya S.Praja, Hukum Islam di Indonesia Perkembangan dan Pembentukan (Bandung: PT. Remaja Rosda Karya, 1991), h. 118. 
bahwa Piagam Jakarta itu menjiwai UUD 1945 dan merupakan suatu rangkaian kesatuan dengan konstitusi tersebut. ${ }^{14}$

Kelima, Teori receptie a contrario. Teori ini menjelaskan keharusan pemberlakuan hukum agama bagi para masyarakat. Hukum adat baru berlaku apabila diterima oleh hukum adat. Teori ini adalah kelanjutan dari teori receptie exit. Selain itu, Sayuti Thalib menyebutkan teorinya merupakan kebalikan dari teori receptie, yang kemudian disebut teori receptio a contrario. ${ }^{15}$

Keenam, Teori Hybrid. Teori ini adalah teori percampuran. Maksud dari teori ini adalah hukum Islam bercampur dengan hukum-hukum lainnya dalam rangka pembangunan hukum Islam. Teori hybrid ini semakin mendapatkan tempatnya apabila ditujukan pada keadilan dan kebutuhan masyarakat.

Selain dari pada enam teori yang dipaparkan, Alquran sebagai sumber utama hukum Islam telah memperkenalkan hukum Islam tidak hanya sebagai sumber hukum. Hukum yang dipaparkan dalam Alquran merupakan bagian dari Aqidah atau keimanan. Aqidah tentang Tuhan yang menciptakan alam semesta, mengaturnya, memeliharanya dan menjaga sehingga segala makhluk itu menjalani kehidupannya masing-masing dengan baik. Hukum Allah meliputi segenap makhluk (alam semesta). ${ }^{16}$

Pemaparan teori-teori di atas dan konsep hukum dalam Alquran, hukum Islam harus memiliki politik hukum dalam pembangunan hukum Nasional. Hal ini tidak terlepas dari fakta sosiologi bahwa hukum Islam dijaga dan dipelihara oleh masyarakat. Sehingga tercipta keadilan yang merupakan tujuan dari berbangsa dan bernegara. Selain itu, politik hukum Islam di masa mendatang harus mengarah, di antaranya; pertama, membangun kelompok yang secara sadar memperjuangkan hukum Islam. Aspek pertama dari ide ini adalah pendalaman terhadap hukum Islam yang rahmatan lil-alamin. Pendalaman hukum Islam untuk menghilangkan kedangkalan pengetahuan dan memberikan penghayatan dalam beragama sekaligus bernegara. Konsep beragama tidak bertentangan dengan

\footnotetext{
${ }^{14}$ Hazairin, Tujuh Serangkai Hukum (Jakarta: Tintamas, 1974), h. 6-7.

${ }^{15}$ Sayuti Thalib, Receptio a Contrario (Jakarta: Bina Aksara, 1982), h. 65-67.

${ }^{16}$ Ernawati, Wawasan Alquran Tentang Hukum (Jurnal Lex Jurnalica, Vol. 13 Nomor 2,
} Agustus 2016), h. 141. 
bernegara. Dua-duanya saling membutuhkan dan melengkapi. Proses ini telah dijamin dalam UUD 1945 Pasal 28E ayat (1), ayat (2) dan Pasal 29.

Masyarakat muslim harus menjadi contoh dalam berislam. Hukum Islam harus diteladankan. Hukum Islam tidak berada di ruang hampa yang tidak memiliki interaksi. Proses ini akan menjadikan kelompok lain menghargai dan menerima hukum Islam sebagai bagian dari fakta sosial, bahwa hukum Islam ada. Selain itu, pemenuhan standar bahwa hukum dianggap masih ada dan hidup adalah dengan cara melestarikannya. Pelestarian hukum Islam haruslah dilakukan oleh pemeluknya untuk menjaga keberlangsungannya.

Aspek berikutnya adalah membangun kelompok yang secara sadar memperjuangkan hukum Islam secara konstitusional. Perjuangan hukum Islam harus konstitusional. Hukum Islam tidak boleh diperjuangkan dalam jalan inskonstitusional.

Kewenangan pembentukan hukum atau legislasi berada di tangan Dewan Perwakilan Rakyat (DPR). Pengaturan ini secara eksplisit dituangkan dalam Pasal 20 ayat (1), 20A ayat (1) dan Presiden berhak mengajukan Rancangan Undang-Undang (RUU) yang diatur dalam Pasal 5 ayat (1). Pembahasan terkait dengan RUU dilaksanakan oleh DPR bersama dengan Presiden (Pasal 20A ayat (2).

Kalau menilik pengaturan terkait pembentukkan Undang-undang, maka cara konstitusional dalam rangka menjadikan hukum Islam bagian dari hukum Nasional adalah dengan mekanisme legislasi yang berada di DPR. Kelompok Islam harus memiliki kesadaran ikut serta dalam pembahasan tersebut. Mekanismenya jelas, menjadi anggota DPR atau DPD dengan jalur pemilihan. Hal ini sebenarnya sesuai dengan salah satu pernyataan Soekarno presiden pertama Indonesia, bahwa penegakkan hukum Islam dalam hukum Nasional atau positivisasi hukum Islam haruslah melalui kursi-kursi di dewan.

Pembentukan hukum yang bernuansa kesepakatan atau Resultante, mengharuskan adanya jalur-jalur kesepakatan. Maka, sudah seyogyanya kelompok Islam mengambil posisi penawaran dan posisi pengambil kesepakatan. 
Hal ini dijamin dalam konstitusi sebagai bagian dari kekuasaan legislasi di DPR dan DPD.

Kedua, pembaharuan (tajdid) dalam hukum Islam dalam konteks Indonesia. Model pembaharuan adalah model yang lumrah terjadi dalam hukum. Hal ini tidak terlepas dari aspek-aspek yang mempengaruhi proses pembentukkan hukum. Sumber hukum Islam yang disepakati jumhur ulama (mayoritas ulama) ada empat, Alquran, hadis, ijma' dan qiyas. Dua sumber hukum Islam yang pertama dan kedua telah terhenti, pertama dengan dicukupkannya wahyu yang turun kepada Rasulullah berupa Alquran dan wafatnya Rasulullah sebagai sumber sunnah.

Sumber hukum yang ketiga dan keempat sepenuhnya diserahkan kepada mujtahid (segolongan orang yang memiliki kualifikasi tertentu) dalam rangka mengeluarkan hukum baru. Ijtihad atau proses pengeluaran hukum tidak boleh melampaui sumber hukum pertama dan kedua. Proses inilah yang sangat erat kaitannya dengan berbagai aspek yang ada pada saat ini atau faktor penentu dalam pengeluaran hukum.

Politik hukum Islam pada masa mendatang harusnya diorentasikan dalam rangka mengisi berbagai kekosongan hukum. Kekosongan hukum dapat memicu konflik di tengah masyarakat. Sudah seyogyanya, para mujtahid mengambil peran ini. Selain memberikan nuansa baru dalam hukum Islam juga mendorong terbentuknya sistem hukum Nasional yang bersumber dari hukum Islam.

\section{Penutup}

Hukum Islam adalah bagian dari tiga sumber hukum Nasional. Selain itu, dasar positivisasi hukum Islam adalah Pancasila. Pancasila yang merupakan sumber dari segala sumber hukum telah memberikan ruang hukum Islam dijadikan sumber hukum Nasional. Hal ini dipertegas dengan Pasal 28 E ayat (1), ayat (2) dan Pasal 29 UUD 1945.

Politik hukum Islam di masa mendatang haruslah diorientasikan kepada dua hal, pertama membangun kelompok yang secara sadar memperjuangkan hukum Islam. Ada dua hal; (1) menjadikan hukum Islam sebagai pedoman 
dipraktekkan dalam kesehariannya; (2) memamasukkan dalam kekuasaan legislasi DPR dan DPD. Hal ini merupakan jalan konstitusional agar hukum Islam memiliki posisi tawar dan posisi penentu dalam hukum Nasional.

Kedua, pembaharuan (tajdid) dalam hukum Islam dalam konteks Indonesia. Hal ini untuk memberikan kebaharuan dalam hukum Islam sekaligus mengisi kekosongan hukum Nasional. Memperhatikan berbagai aspek dan berbagai faktor yang berkembang di masyarakat. Sehingga hukum Islam memiliki kontribusi dalam pembentukkan hukum Nasional. 


\section{Daftar Pustaka}

Ali, Ahmad. Menguak Tabir Hukum. Bogor: Ghalia Indonesia, 2011.

Ernawati. Wawasan Alquran Tentang Hukum. Jurnal Lex Jurnalica, Vol. 13 Nomor 2, Agustus 2016.

Gibb, H.A.R. Modern Trends In Islam. Chicago: The University of Chocago, 1972.

Hazairin. Tujuh Serangkai Hukum. Jakarta: Tintamas, 1974.

Ichtiyanto. Pengembangan Teori Berlakunya Hukum Islam di Indonesia," dalam Juhaya S.Praja, Hukum Islam di Indonesia Perkembangan dan Pembentukan. Bandung:P.T. Remaja Rosdakarya, 1991.

Kamsi. Politik Hukum Islam Pada Masa Orde Baru. Jurnal Ishraqi, Vol. 10, No. 1, Juni 2012.

Lev, Daniel S. Peradilan Agama Islam di Indonesia Suatu Studi Tentang Landasan Politik Lembaga-lembaga Hukum, Alih bahasa oleh Zaini Ahmad Noeh. (Jakarta: Intermasa, 1986).

Mardani. Kedudukan Hukum Islam dalam Sistem Hukum Nasional. Jurnal Hukum No. 2 Vol. 16 April 2009

Mudzakir. Integrasi Hukum Islam dalam Hukum Nasional: Upaya Restrukturisasi Perundang-undangan Nasional. dalam Jurnal Mazhabuna, No. 2 Tahun II/2003.

Mertokusumo, Sudikno. Mengenal Hukum. Edisi Revisi, Yogyakarta: Cahaya Atma Pustaka, 2010.

Ngutra, Theresia. Hukum dan Sumber-Sumber Hukum. Jurnal Supremasi: Volume XI Nomor 2, Oktober 2016.

Saleh, Roeslan. Penjabaran Pancasila dan UUD 1945. Jakarta: Aksara baru, 1979.

Salam, Abus. Pengaruh Politik Dalam Pembentukan Hukum di Indonesia, Mazahib: Jurnal Pemikiran Hukum Islam, Vol. XIV, No. 2, Desember 2015.

Thalib, Sayuti. Receptio a Contrario. Jakarta:Bina Aksara, 1982. 